\title{
Online Learning Science through STEAM based on the Local Wisdom
}

\author{
Corrienna Abdul Talib ${ }^{1}$, Faruku $\mathrm{Aliyu}^{2}$, Subuh Anggoro ${ }^{3}$ \\ \{ corrienna@utm.my ${ }^{1}$, faruk.aliyu@ssu.edu.ng ${ }^{2}$, subuhanggoro@ump.ac.id ${ }^{3}$ \} \\ ${ }^{1}$ Universiti Teknologi Malaysia, Malaysia \\ ${ }^{2}$ Sokoto State University, Nigeria \\ ${ }^{3}$ Universitas Muhammadiyah Purwokerto, Indonesia
}

\begin{abstract}
Recently problems in science education during the Covid-19 pandemic era are focusing on how to engage students in the online science classroom. There is a lack of exploration in learning experiences that engage students in virtual, thought-provoking problems, working with peers, and applying their $21^{\text {st }}$-century skills as problem solver to real-world problems. One of the biggest challenges for secondary schools is that few guidelines or models exist regarding teaching science to engage students in the online classroom. Having this in mind, this study provided a systematic and analytical strategy in mapping out and offering a critical review of the integration of local wisdom of online science learning. Overall, this study recognized the gains that can be made from utilizing local wisdom in education, especially in the global quest of teaching 21 st-century skills, and had recommended using local wisdom in instructional design. This paper also suggested a need to pursue further studies on developing a local wisdom framework for students easily master science learning media and how these could motivate and excite students and themselves in the teaching and learning process of the online science classroom.
\end{abstract}

Keywords: STEAM, online science learning, design thinking, local wisdom

\section{Introduction}

Science education involve strategies of how effective teaching and learning of science should be carried out been it an amalgam of cognitive activities with both practical demonstration and emotional engagement. It is however, accompanied with myriad of issues and challenges that affect learners perception ang the general learning practice around the globe [1]. Some of these challenging issues at stake includes the nature of science textbook which relatively overemphasized on the factual information, scientific language in the textbook, lack of clear and personal relevance to the learners due to the abstract and intangible concept and entities. Also, part of the issues is the traditional teaching and learning strategy utilized in school which gives emphasis to emphasis on students' activeness and involvement in the lesson making the class a teacher dominated classes. These challenging issues make science and science education seems a boring and difficult subject for the teachers to teach and students to learn making it problematic for them to see and establish connections between the subject and their real life personal and social life thereby losing interest and curiosity to learn the concepts.

In relation to the challenging issues with the science education, it is expected that teaching and learning of the subject to be unique, innovative, and interactive to establish the needed connection between the subject the societal life. Despite these expectations, the strategies utilized in most school to teach science is outdated and in effective most especially in this era 
of pandemic where online learning is the unavoidable being it the only option if the teaching and learning must be carried out. In the traditional learning strategy, a teacher is regarded as the main source of knowledge responsible for transmitting it to the learners neglecting students right to present their ideas, knowledge and understanding in generating and developing conceptual meaning and understanding of scientific concepts. Hence students lack necessary wisdom, skills and connection that could guide them learn concept particularly when they far and distanced from their teachers (i.e. Online learning) where there is a lack of exploration in learning experiences that engage students in virtual, thought-provoking problems, working with peers, and applying their $21^{\text {st }}$-century skills as problem solver to real-world problems Having this in mind, one may think of other possible means of establishing wisdom and learning skills among students that could support their learning even when they are far from their teachers. In this attempt local wisdom would in no doubt be part of what could appear to serve as substitute since in every culture and society, there are skills and experiences that could be scientifically proven and support the learning of science.

Local wisdom is a life view and strategy of life regarding activities carried out by the local society in an attempt to respond to societal problem and arriving at the solution to their needs. It often referred to as local knowledge and skills for solving societal problem. Local wisdom is regarded as unique skills, intelligence and way of doing things by a certain culture or ethnic group resulting from a result of experience which may be uncertain experience by other ethnic group perspectives [2]. This is due to the fact that some norms and values where considered strong by certain ethnic group even though is less strong to others. In the educational perspectives local wisdom may manifest and function superiority in the aspect of art, language, economy, culture, technology and human resources, and when properly injected into the school curriculum could actively enhance students' growth and development in skills and competency for the global challenges and competition. When local wisdom is properly developed and utilized students could develop moral character and manage social life which in essence aimed at reforming the character of young generation regarding socio-cultural issues for better future generation. Local wisdom also functions as a source of good personality in interaction, creativity, success motivation, cultural industry deposit for societal prosperity. When these skills and issues are developed in students, they are expected to effectively and actively participate in the learning of concepts most especially that of science nature in the era of online learning and acquire $21^{\text {st }}$ century skills for personal development in respect of social, psychological and moral perspectives and national development in term of scientific, technological, and economic perspectives.

Hence, in order to engage in online learning which does not involve face to face interaction between the students and facilitator, skills of such kind as local wisdom need to be given due consideration. This is in order to develop guidelines or models regarding- teaching science to engage students in the online classroom which is one of the biggest challenges for teaching of secondary schools students in the online platform. Therefore, this study provided a systematic and analytical strategy in mapping out and offering a critical review of the integration of local wisdom of online science learning thereby presenting the gains that can be made from utilizing local wisdom in education, especially in the global quest of teaching 21 st-century skills.

\section{From STEM to STEAM}

Knowledge of science, technology, engineering and mathematics and ability to connect and apply them appropriately and thoughtfully is critical in making wise personal decision, and compete in the ever-increasing global economy. schools and colleges all through from different nations-including China, Australia, the United Kingdom, France, and Taiwan-have 
embraced STEM-centered educational plans. The STEM disciplines are designing, math, science, brain research, financial aspects, agrarian sciences, and other social sciences. STEMjust advocates content that a STEM-taught labor force is fundamental to the age of groundbreaking thoughts, adaptability, and basic reasoning [3]. The attention on STEM has likewise furnished many nations with a questionable benefit in science and innovation. As indicated by the most recent report from the National Science Foundation, while making sure that the worldwide forerunner in science and innovation, that lead is contracting as different nations keep on making progress. STEM was once alluded as Science, Technology and Society (STS) in the far off past and point is to prepare people with forward-thinking information in the partnered disciplines to fulfill the current need of the general public and to move the restriction of human reasoning and critical thinking capacity which might bring about significant turn of events and worked on living. Truly, Science, Technology, Engineering and Mathematics, originates before its homeroom instructing. It application likewise existed prior to formalizing the methodology in learning [3]. Every one of these fields and trains associated are currently being concentrated from the most rudimentary phase of homeroom instructing to the most elevated level of formal schooling in the created world.

STEAM is an educational learning method that uses science, technology, engineering, art, and mathematics as entry points to guide students' inquiry, dialogue, and critical thinking [4]. The end result is allowing students to take thoughtful risks, engage in experiential learning, continue to solve problems, embrace cooperation, and work through creative processes. They are the innovators, educators, leaders and learners of the 21 st century.

STEAM involved the integration of art, a teaching and learning method, through which content standards are fairly taught and assessed in and through art. It is intended to combine academic instruction (generally math, science, social studies, English, and language arts) with artistic disciplines such as visual arts, dance, music, and theater.

STEM is expected to delve into four component areas. Students in STEM courses are usually seen as learning opportunities with more experience, but they are limited to science, technology, engineering, and mathematics. The national economy needs more than just understanding these areas [5]. Application, creativity and originality in STEM-related fields are also an important part of solving the challenges of daily life. STEAM introduces different dimensions to the way STEM education is carried out in the classroom. Before the era of robots, art brought diversity to packaging. According to Taylor STEAM always provides opportunities for students to share their learning experiences in these key areas, as well as artistic practices, elements, design principles, and standards [6]. STEAM can be said to have replaced its predecessor with breadth, criticism, research, and innovation. In another narration Stoelinga et a. STEAM reported that the United States has achieved groundbreaking success in implementing the curriculum. Other reports of learning activities that include the integration of science, technology, and the arts point to positive differences in attracting minority and disadvantaged students to improve literacy and numeracy skills [7]. The concept of STEAM education is not the opposite of STEM education, but it enriches and expands the scope of STEM education. The STEAM curriculum allows science teachers to participate in the development of the school curriculum. It allows students to participate in transformative learning based on five interconnected and interdisciplinary forms of knowledge: cultural self-knowledge, relational knowledge, critical knowledge, foresight and moral knowledge, and empirical knowledge. In addition, Sofia et al. outlined that STEAM makes teaching and learning interesting and fun to attracts both teachers and students [8]. The reason why art integration is widely adopted students easily learn and retain more content serving as a better way of teaching STEM components. 
A science mastery is truly important, yet the feeling of compassion that comes from music, expressions, writing, and brain research gives a major benefit in plan. A clinician is bound to realize how to rouse individuals and to get what clients need than is an architect who has worked uniquely in the innovation channels. When settling on their own decisions in the STEM versus STEAM training banter, states all through the nation can exploit greater adaptability to join STEAM

A new report supported by the National Endowment for the Arts tracked down that an information base and appreciation for expressions of the human experience coming from a STEAM schooling approach really converted into a more exact pathway to school.

With a STEAM instruction, students can investigate a more extensive scope of interests; some may normally dominate in science and innovation, and others might appreciate investigating their imaginative side. It is perceived that the benefit of empowering youngsters to foster their own special abilities - in whatever discipline it could be - and be steady of their decisions in instruction and vocation. In the struggle for establishing a conducive learning involving STEAM education most especially in online learning, local wisdom may play crucial role.

\section{Issues in Science Learning}

Generally, the role science education in today's global education system and national development cannot be over-emphasized making the discipline to be much more than the factbased knowledge. Hence, science is incomprehensible and meaningless if the learners are not able to relate their learning with real life situations and solve problems of life. Some of the challenging issues with regard to teaching of science (i.e. science education) are tabulated below 


\begin{tabular}{ll}
\hline \hline \multicolumn{1}{c}{ Issue } & \multicolumn{1}{c}{ Description } \\
\hline \hline Financial crunch in academia & $\begin{array}{l}\text { Inadequate financial support for science teaching } \\
\text { bedevilled many developing nation's success in } \\
\text { delivering the science curricular [9-11] }\end{array}$ \\
\hline science syllabi, textbooks and & $\begin{array}{l}\text { In many nations there are well-planned curriculum } \\
\text { content knowledge }\end{array}$ \\
& $\begin{array}{l}\text { regarding science and technology but it clearly translated } \\
\text { knowledge is missing here. Hence, science teachers } \\
\text { hardly plan science lesson that connect the syllabi and } \\
\text { textbook with curriculum [1] }\end{array}$
\end{tabular}

reform in science teacher education program Even though science teachers are regarded as implementers of planned science programme in the science classroom, they however, lacked skilled and content knowledge. This highpoints the need of preservice and in-service teachers to be trained in order to provide bases for developing knowledge, skills, and experience to discuss issues, and put ideas into practice [1]

methodological and instructional approaches The mono-methodological traditional approach that emphasized passive learning classes and penalized empiricism, critical thinking and creativity in students as teacher-centered strategy to science humiliated and deemphasized participatory pedagogy [12]

resources and school facilities One of the challenges constraining the teaching of science is the non-availability of science teaching and learning resources [13]

Lack of local wisdom Mastery of learners to the concept of science content available in the local wisdom of their tribal communities is very low. Hence, it is necessary to integrate of local wisdom in the leaning of science is very crucial [14]

Table 1: Summary on issues in science Education

\section{Local Wisdom and the Learning of Science}

Culture and knowledge are hot topics in today's society. Discussions were made in various works on print media, interviews and electronic media dialogues. Several alternative solutions were proposed, one of which was widely proposed to overcome, at least to reduce the cultural issues or local wisdom and knowledge discussed through education, that is, formal school education [15]. Recently, learning is more and more serious about answering questions related to students' culture and knowledge. The solution provided is to deal with these problems through education. Innovation in education is innovation in teaching materials. Formal education is a learning process that takes place in a structured way in school, which aims to transfer knowledge and provide a good example to train students with emotional, psychomotor and cognitive value. The success of school education is highly dependent on the ability of teachers, including knowledge and teaching ability.

Silaban in Hadi and Manurung noted that when educators only focus on traditional textbooks without creatively developing them in innovative ways, the quality of learning is low 
[15]. Good textbooks refer to textbooks developed according to their needs for use or the characteristics of the students, the curriculum, and the purposes of learning. Talking to users about the applicability of teaching materials is inseparable from the activities or activities that students carry out in community life. Parmin et al. revealed that applying the values of local wisdom to learning can provide a real learning process and preserve one's own knowledge of local wisdom [16].

Scientific learning media can effectively enhance students' scientific attitudes toward science, scientific process skills, and student mastery of scientific materials. The combination of scientific learning and the local potential that surrounds it can cultivate the student's ability to observe and conduct experiments independently [17]. In addition, students will be able to learn more about the potential of their field, which will allow students to become accustomed to searching, processing, and finding information on their own, and using this information to solve problems in the environment. Science-based learning and the integration of local wisdom can enhance students' scientific process skills and scientific attitudes.

Research results are related to research results Through these research results, it is found that the developed local potential combined with scientific learning can effectively enhance the scientific process skills and scientific attitudes of students. A research conducted by Wilujeng, Zuhdan and Suryadarma (2019) concluded that local wisdom significantly impact science process skills and scientific attitude among learners simultaneously. This is because the local wisdom makes learners experience a more meaningful science learning since the learning is connected to what they are familiar with right from their home which in return improve learning outcomes.

The science-based learning that uses local facilities serves as a learning model that stresses on the learners' creativity in connecting new ideas with the existing one necessary for the learning process to take place. Learning by using the local wisdom emphasizes activeness and involvement of the learners in the learning activitiesThe use of local wisdom in learning also confirms that science learning not only understands concepts, but also strengthens Indonesia's sense of identity with its different cultures. The teaching of science linking cultural values with modern science has a good relationship, especially when science is taught to students in indigenous communities.

\section{Conclusion}

The significant effect revealed by the students' literacy in local wisdom on the leaning of science re-iterated the need for the stakeholders in science education to amend the science curriculum thereby integration of local wisdom skills and practices available in the students' respective communities. By implication learners could view and perceived learning of scientific concepts as a continuation of the home-based knowledge they acquired, and their parent too could serve as facilitator's particularly in this era when online learning is unavoidable due global issues such as Covid-19 pandemic. At this point domain-based learning media enhancing science process skills and scientific attitude among the learners could simultaneously be promoted. The action called for the science teachers to implement learning that emphasize not only cognitive aspect but also the psychomotor and the affective aspect within learners. Further studies could be carried out on developing a local wisdom framework for students to easily master science learning media and how these could motivate and excite students during teaching and learning process of the online science classroom. 


\section{References}

[1] Jessani SI. Science education: Issues, approaches and challenges. Journal of Education and Educational Development. 2015 Jul 11;2(1):79-87.

[2] Tanjung P, Daulay S, Ghafari OF. The development of local wisdom of Labuhanbatu based on teaching material of descriptive text for 7th Grade student at SMP Negeri 1 Bilah Barat, Indonesia. International Journal of Education, Learning and Development. 2018 Jan;6(1):8092.

[3] Badmus OT, Omosewo EO. Evolution of STEM, STEAM and STREAM Education in Africa: The Implication of the Knowledge Gap. International Journal on Research in STEM Education. 2020 Nov 30;2(2):99-106.

[4] Colucci-Gray L, Burnard P, Gray D, Cooke C. A critical review of STEAM (Science, technology, engineering, arts, and mathematics). Oxford research encyclopedia of education. 2019 Mar 26.

[5] Boy GA. From STEM to STEAM: toward a human-centred education, creativity \& learning thinking. InProceedings of the 31st European conference on cognitive ergonomics 2013 Aug 26 (pp. 1-7).

[6] Taylor PC. Why is a STEAM curriculum perspective crucial to the 21 st century? Research Conference 2016, 89-93.

[7] Stoelinga SR, Silk Y, Reddy P, Rahman N. Turnaround Arts Initiative: Final Evaluatiion Report. President's Committee on the Arts and the Humanities. 2015 Jan.

[8] Sofia HW, Utomo AP, Hariyadi S, Wahono B, Narulita E. The validity and effectivity of learning using STEAM module with biotechnology game. JPBI (Jurnal Pendidikan Biologi Indonesia). 2020 Mar 31;6(1):91-100.

[9] Bamigboye G, Ede AN, Adeyemi GA. Impact of economic crisis on education: case study of southwest Nigeria. INTED $2016 \quad$ Proceedings, 1(November), 2893-2896. https://doi.org/10.21125/inted.2016.1650

[10] Gibbs WW, Fox D. The false crisis in science education. Scientific American. 1999 Oct $1 ; 281(4): 86-93$.

[11] Shafiq MN. The effect of an economic crisis on educational outcomes: An economic framework and review of the evidence. Current Issues in Comparative Education. 2010;12(2):5-13.

[12] McFarlane DA. Understanding the challenges of science education in the 21st century: New opportunities for scientific literacy. International Letters of Social and Humanistic Sciences. 2013(04):35-44.

[13] Boakye C, Ampiah JG. Challenges and solutions: The experiences of newly qualified science teachers. Sage Open. 2017 May;7(2):1-10. https://doi.org/10.1177/2158244017706710

[14] Nasrudin D, Suhada I, Rochman C, Helsy I, Hermawan AH. Polyculture strategy: Integration of islamic values, national character, and local wisdom in science learning. InProceedings of the International Conference on Islamic Education (ICIE 2018) 2018 (Vol. 261, No. ASSEHR, pp. 236-239). Atlantis Press.

[15] Hadi K, Manurung B. The Effect of Teaching Materials Based on Local Value Integrated by Character Education through PBL Models on Students' High Order Thinking Skill. Britain International of Humanities and Social Sciences (BIoHS) Journal. 2019 Oct 10;1(2):213-23.

[16] Parmin P, Sajidan S, Ashadi A, Sutikno S. Skill of teacher candidates in integrating the concept of science with local wisdom. Jurnal Pendidikan IPA Indonesia. 2015 Nov 2;4(2):120-126. https://doi.org/10.15294/jpii.v4i2.4179

[17] Wilujeng I, Prasetyo ZP, Suryadarma IG. Integrating Local Wisdom in Natural Science Learning. InProceeding of the 1st Internasional Conference on Innovation in Education 2018 (Vol. 178, pp. 182-186). 